\title{
An Annotated Bibliography on the Rabbit Novels by John Updike
}

\section{Luis Gustavo Álvarez Martínez}

Universidad Nacional, Costa Rica

\section{RESUMEN}

Se presenta un registro comentado de los principales estudios, libros y artículos sobre la serie narrativa del novelista estadounidense John Updike, conocida bajo el título común de novelas sobre Cone jo (Corre, Conejo; El regreso de Conejo; Conejo es rico, etc.).

\section{Abstract}

This annotated bibliography includes a brief introduction to the Rabbit novels and comments on the main studies, books and articles on these novels by the U.S. writer John Updike (Rabbit, Run; The Redux of Rabbit; Rabbit Is Rich, etc.).

Several contemporary American writers have received outstanding critical acclaim in recent years. However, few have become more a subject of controversy than John Updike. Each of his successive Rabbit novels has brought forth additional comments by all major critics as well as generating interesting discussions in the popular press. Updike is accused of poor taste and repellent characterization; however, his manner of handling language is considered unmatched by other writers of his generation. He has won numerous awards and honors and is widely regarded as one of America's great novelists. 
This annotated bibliography of the first three Rabbit novels Rabbit, Run (1960), Rabbit Redux (1971), and Rabbit Is Rich (1981) covers work from 1967 until 1991. Rabbit Angstrom has become Updike's best-known character, and Rabbit, Run is his most recognized book title. In this bibliography, the materials have been divided into books, essays and periodical articles and a symbol, an asterisk, is used throughout the bibliography to indicate that the source could not be found due to time limitations or inaccessibility of materials.

The dates above mentioned are very significant because they cover three decades which are very rich in terms of history for the American people. There are intervals of approximately ten years between the publication of each of his books. For example, the first edition of Rabbit, Run appeared in 1960 and the last book of the trilogy, Rabbit Is Rich, was published in 1981. Thus, all the political, religious, financial, social and historical events depicted in the novels are well-documented in this research covering a time span of thirty years, which is enough time for researchers and scholars to have written widely about this trilogy and its impact during the specified period.

As Rabbit, Run opens, twenty-six-year-old former high school basketball star Harry Angstrom is on his way home from his unfulfiIling job as a demonstrator of a kitchen gadget, the MagiPeel vegetable peeler. He watches some kids playing basketball and joins their game, fantasizing about his lost days of glory, then runs home to his tiny apartment. There his wife, Janice, who is pregnant, asks Rabbit to go get their car, pick up their son, Nelson, and get her some cigarettes. This string of errands weighs on Rabbit, who feels trapped and bored in his job, his marriage, his demanding mistress and his life. He sees his son through the window of his in-laws' house and decides to leave him in their care. On impulse, Rabbit gets in the car and starts driving south, away from his old life. He is trapped in an unfulfilling life and his equally unfulfilling attempts to leave his family and find a new life. 
In Rabbit Redux, Harry Angstrom finds his dream life shattered by the infidelity of his wife. He is inactive, thirty-six years old and not particularly engaged in any aspect of his life whatsoever. He seems awash in the currents of life swirling around him, and is either willing to go along with anything, or utterly unwilling to make his own choices. In the opening chapters, his wife Janice leaves him for a man she works with in her father's car lot. Harry just lets her go, maybe because he did the same thing years before. He falls quickly in with some shady characters, and is soon shacking up with an 18 year-old girl and a scary militant black man. It is the end of the 1960s, and the violent and revolutionary nature of the times invades Harry's life. He just lets it all sweep in and take over his existence, but his disengagement and amoral detachment make for some ugly happenings to come.

Rabbit Is Rich is the third of John Updike's five Rabbit novels, all of which focus on their central character Harry Angstrom. In this novel, Harry has come to enjoy considerable prosperity as Chief Sales Representative of a Toyota agency in Pennsylvania. With their finances finally solvent and their marriage somewhat stable, Rabbit and his wife have joined a country club for the affluent middle class and have a new circle of friends. The time is 1979: Skylab is falling, gas lines are lengthening, the President collapses while running in a marathon, and double-digit inflation coincides with a deflation of national confidence. Nevertheless, Harry feels in very good shape, ready to enjoy life at last - until his son, Nelson, returns from the West, and the image of an old love pays a visit to his lot. New and old characters populate these scenes from Rabbit's middle age, as he continues to pursue happiness.

The major collection of Updike's papers is at the Houghton Library of Harvard University with 365 manuscripts, 18 letters written by him, 2868 items of correspondence and 9 documents relating to the author. The Library of Congress has 91 manuscripts, typescripts and proofs of his works.

One of the manuscripts, (MS 691), offers us one of the sources of Rabbit's examples of people's impatient and volatile behavior at the 
gas lines. One source included in this manuscript which is worth mentioning is the piece of news from the Boston Sunday Globe (July 8,1979 ), whose lead-in reads as follows: "The nation's first gasoline riot, not surprisingly, occurred at the point where the American Dream met the energy crisis" (Ristoff 141).

In regard to the biographies, as expected, Greiner (8) and Helterman (10) offer good biographical information focusing on Updike's life and his poetry. But very little information is directly related to the novels. The same situation happens with the bibliographies in which Taylor (18) and Spiller (16) present interesting annotations explicating the controversies about Updike's religious themes discussed in periodicals. However, there is again very little relevant information focusing on the Rabbit novels.

To mention some of the best books found in this research, I will start by citing Ristoff (13), which is an interesting study of the Rabbit trilogy from a Latin American point of view. He studies the novels from a culturally-oriented perspective where the American lifestyle generates moods, conflicts and actions of the characters. At the same time, they reveal the ideological spectrum of America during the ' $50 \mathrm{~s}$, '60s and '70s. Similar to this is Greiner (6) who gives an interesting analysis of the novels, focusing on what the main character does during the three decades encompassed in the novels. Finally, Burchard (4) explains Rabbit, Run from a religious point of view stressing the necessity of human beings to search for God in order to fit the needs of this contemporary society.

Some of the most influential academic essays found pertaining to Updike are Brenner (26) and Slethaug (30). The former discusses the loss of traditional values in American society, while the latter analyzes the characters in Rabbit Redux in relation to the treatment of freedom. He agrees with Updike's view of the irresponsible use and abuse of freedom by Americans.

A great variety of topics such as religion, sex, racism, adultery and Updike's use of animal imagery have been widely discussed by 
many different critics in periodical articles. For example, Ahearn (31) shows how adultery is a major theme that leads to the chaotic situation in the marriages portrayed in the Rabbit novels. Sex and religion in relation to the characters are discussed by Falke (44), Horvath (46) and Hunt (48). They all analyze the relationship between sex and characters stressing Updike's religious themes. These authors also discuss the vulgar and obscene aspects of the novels.

Some pejorative comments on the novels are made by critics such as Ricks (62) who gives a negative review of Rabbit Redux. He thinks that Updike "overprotects" his characters giving them no chance to react to the events of the time. This opinion is echoed by Lasseter (52) in his critique of Rabbit Is Rich; he also contends that Updike's characters have little freedom of choice. This restriction of freedom is what makes this novel a naturalistic one. Finally, Samuels (63) criticizes Updike's Rabbit Redux because the novel is not strong in fathoming causes and asserting judgments.

An important aspect that captured my attention during this research is the changes in sexual references in the most recent editions of Rabbit, Run. Waldron (69) points out the differences in the three revised texts of Rabbit, Run that may escape to scholars and critics. He talks about changes in words related to sex like the word loving instead of $f$--ing.

Even more, Wilhem (70) and (71) explains how readers and scholars can be totally unaware of Updike's changes because editors continue to print the original text published by Alfred A. Knopf in 1960. In addition, many critical essays continue to cite the original text and simply ignore the variants in chronology where the word "yesterday" is changed to "Monday" in pages 261-262. Moreover, the shifts in verb tense from the present to past and the stylistic changes involving diction-searching for more precise words-are still unnoticed by most readers.

Updike's probable motives in revising Rabbit, Run were to correct factual inconsistencies, to enhance the "trap" imagery and 
to clarify the character of Eccles. But above all, he wanted to restore a number of sexually explicit passages in his 1960 manuscript that were deleted at the behest of Knopf's legal department. The changing social climate of the late " 70 s permitted these expurgations to be reinserted when Updike was in France working on his book.

There appears to be a broad diversity of opinion as to which novel is considered Updike's best work. To give an example, I will mention Edwards (41) and Hunt (47) in regard to the novel Rabbit Is Rich. They both considered this novel the best of the three because of the manner in which Updike portrays the economic situation of the "70s.

On the other hand, Ellison (42) criticizes the same novel because it shows more of Rabbit's regretting the passage of time than enjoying the richness of the present. He thinks that "Rabbit Is Sad" would have been a more appropriate title. So, this division among critics is just a matter of taste and probably Updike's fourth novel Rabbit Rest (1990) or his fifth novel Rabbit Remembered might possibly be the best of all the novels.

In fact, this research shows that a wide range of topics and information have been covered to present readers with a general background of the American history depicted in Updike's novels. Even though there are bibliographies on Updike such as Taylor (18) and Spiller (16) which present annotations based on religious themes, this annotated bibliography is the only one that focuses specifically on the trilogy of the Rabbit novels. This research will certainly contribute to the study of the topic on Updike's Rabbit novels. Nevertheless, I notice that issues such as sex, religion, adultery, analysis of historical and political events have been written about vastly in Rabbit, Run and Rabbit Redux.

In regard to Rabbit Is Rich, there is very little critical information written about it and there is no doubt that much more needs to be done to balance the general scope of the three novels. Therefore, among some topics which have not been addressed at all and can be developed in the future are the following: 
- $\quad$ Postmodernism and the Space Age

- The role of media and its impact on people

- Rabbit as an archetypal hero (the New American Adam)

- The loss of values and domestic violence in the novels

- Application of the theory of time (the eternal return)

- Myths and the American Dream

- Culture circumscribed by television

- The role of women in the novels

- $\quad$ Pop culture references

- Rabbit's misogyny

Probably within the next years scholars and critics will provide more information about the novel Rabbit Is Rich and its sequel Rabbit Rest as well as Updike's fifth and last novel Rabbit Remembered, leaving open the possibility to expand and update this annotated bibliography, which is a very useful guide to all serious students of literature and to anyone interested in working specifically on Updike's Rabbit novels.

\section{A. Books}

(1) Updike, John. Rabbit, Run. $1^{\text {st }}$ ed. New York: Knopf, 1960. Rabbit Redux. $1^{\text {st }}$ ed. New York: Knopf, 1971. Rabbit Is Rich. $2^{\text {nd }}$ ed. New York: Knopf, 1981.

Shows Updike's most substantial changes in revising the $1^{\text {st }}$ edition. Restores sexually explicit passages that were deleted from the previous version of Rabbit Is Rich.

(4) Burchard, Rachel. John Updike: Yea Sayings. Carbondale and Edwardsville: Southern Illinois UP, 1971. 
Explains the search for religion in Rabbit, Run to fit the needs of individuals (Harry) in contemporary society. Positive view of Harry toward his ideals and beliefs.

(5) Detweiler, Robert. John Updike. New York: Twayne Publisher, 1972.

Offers criticism of the novels Rabbit, Run and Rabbit Redux, focusing on the metaphoric language and image patterns that mark their style. Praises Updike for being an impeccable observer of thoughts and feelings.

(6) Greiner, Donald J. John Updike's Novels. Athens: Ohio University Press, 1984.

Provides an interesting analysis and interpretation of the Rabbit novels focusing mainly on what Harry does during his three decades. Presents Harry as a sexist, dumb and lazy character who not many people like, but his author.

(7) Adultery in the American Novel: Updike, James and Hawthorne. $1^{\text {st }}$ ed. Columbia S. C: University of South Carolina Press, 1985.

Presents the role of adultery in the American novel comparing different authors. Little emphasis on the Rabbit novels is given; however, in Rabbit, Run Harry is considered a terrible father, an inadequate husband and an unreliable lover.

(8) Greiner, Donald, ed. American Poets Since World War II. Detroit: Gale, 1980. Vol. 5 of Dictionary of Literary Biography. 
Offers biographical information about Updike life focusing mainly on his poems; not much information related to the Rabbit novels.

(9) Hamilton, Alice and Kenneth. The Elements of John Updike. Grand Rapids, Mich.: William B. Eerdmans Publishing Co., 1967.

Points out the elements of fiction that give Rabbit, Run the feeling of pace and action-plot. Very good information regarding setting and atmosphere and how these contribute to the plot.

(10) Helterman, Jeffrey, and Richard Layman, eds. American Novelists since World War II. Detroit: Gale, 1978. Vol. 2 of Dictionary of Literary Biography.

Gives good biographical information focusing on Updike's life as well as on his works Rabbit Redux and Rabbit, Run. The former is criticized for not providing a good style of Updike's fiction.

(11) Macnaughton, William R. Critical Essays on John Updike. Boston: G.K. Hall, 1982.

Good criticism and interpretation including some essays on Rabbit, Run and Rabbit Redux. Interesting view of the social and political issues of the sixties and their consequences during the next decade.

(12) Markle, Joyce B. Fighters and Lovers: Theme in the Novels of John Updike. New York: New York UP, 1973. 
Similar to Burhans (25); however, this is a better examination of themes and characters including Rabbit Redux which is rich in intelligence, wit and imagination.

(13) Ristoff, Dilvo I. Updike's America: The Presence of Contemporary America History in John Updike's Rabbit Trilogy. Vol. 2. New York: Peter Lang, 1988.

Well-written study of the Rabbit trilogy that reveals the ideological spectrum of America in the fifties, sixties and the seventies. A brilliant portrait of middle America.

(14) Sann, Paul. The Angry Decade: The Sixties. New York: Crown, 1979.

Focuses on social problems such as racism and war depicted in Rabbit Redux. Sann shows the chaotic situation Americans were experiencing and that led to the riots in the sixties.

(15) Searles, George. The Fiction of Philip Roth and John Updike. Carbondale: Southern Illinois UP, 1985.

Evaluates Updike's fiction of the Rabbit novels in relation to Roth novels. Similarities of themes such as cultural disintegration, dissolution of marriage and family life.

(16) Spiller, Robert, ed.Literary History of the United States: Bibliography. $4^{\text {th }}$ ed. New York: Macmillan, 1974.

Enumerative bibliography of his works from 1959 until 1971, giving very little information about Rabbit, Run and nothing about the two other novels. 
(17) Tallent, Elizabeth. Married Man and Magic Tricks: John Updike's Erotic Heroes. Berkeley: Creative Arts Book, 1982.

Focuses on Rabbit, Run with an interpretation of the main hero in relation to the treatment of women in the novel. Thinks that the role of female characters is not interpreted according to the time.

(18) Taylor, C. Clarke. John Updike: A Bibliography. $1^{\text {st }}$ ed. Kent, Ohio: Kent State UP, 1968.

Annotated bibliography listing Updike's works from 1949 until 1967; however, not much useful information about the Rabbit novels.

(19) Thorburn, David, and Howard Elland, eds. John Updike: A Collection of Critical Essays. Englewood Cliffs, NJ: Prentice, 1979.

Includes four interesting critical essays based on the Rabbit novels. Similar to Sann (14), giving more emphasis to the social aspects of Rabbit Redux and how these aspects are a reflection of the American people.

(20) Updike, John. Self-Consciousness: Memoires. $1^{\text {st }}$ ed. New York: Knopf, 1990.

Provides an interesting personal presentation of his life and family; however, not very relevant to the Rabbit novels.

(21) Uphaus, Suzanne H. John Updike. New York: Ungar, 1980.

Gives an interpretation of characters and imagery in Rabbit, Run and Rabbit Redux to demonstrate the confusion and 
uncertainty of contemporary society. The former is praised because what redeems Harry is that inside his brutish exterior, he is tender and feminine.

(22) Vargo, Edward P. Rainstorms and Fire: Rituals in the Novels of John Updike. Port Washington, NY: Kennikat Press, 1973.

(23) Vaughan, Philip H. John Updike's Images of America. Reseda, California: Mojave Books, 1981.

Points out religious and ritual aspects in Rabbit, Run and Rabbit Redux according to their character's actions. Very good article in terms of symbolism.

B. Essays

(24) Alter, Robert. "Updike, Malamud, and the Fire This Time." Thorburn (19). 39-49.

Concludes that different white writers show the wave of racial paranoia in their novels through their character's actions and behavior.

(25) Burhans, Clinton. "Things Falling Apart: Structure and Theme in Rabbit, Run." Macnaughton (11). 148-62.

Examines the theme and structure of the novel in which Rabbit runs in circles unable to find any clear meaning for direction. Anyone except him can see where it will end.

(26) Brenner, Gery. "Rabbit, Run: John Updike's Criticism of the Return to Nature." Macnaughton (11). 91-104. 
Among the most influential academic essays on Updike, discussing the loss of traditional values because the sense of duty is aroused only by natural events. Brenner believes that Updike wrote a scandalous novel on purpose to capture the attention of the reading public.

(27) Doner, Dean. "Rabbit Angstrom's Unseen World." Thorburn (19). 17-34.

Analysis of Harry in Rabbit, Run as symbol of all Americans this being part of the success of the novel. Harry's dreams and desires as an extension of the American quest for happiness.

(28) Gilman, Richard. “An Image of Precarious Life.” Thorburn (19). 13-16.

Critical essay focusing on the dream of freedom in Rabbit, Run as a grotesque allegory of American life. Negative view of the way Americans face life in terms of freedom.

(29) Locke, Richard. “Rabbit's Progress.” Thorburn (19). 35-38.

Brief critical view of the static and dynamic social problems faced by the hero in Rabbit, Run and Rabbit Redux.

(30) Slethaug, Gordon E. "Rabbit Redux: Freedom Is Made of Brambles." Macnaughton (11). 237-53.

The main characters in Rabbit Redux on the treatment of unrestricted freedom without personal responsibility. Good essay in terms of ethical issues. 


\section{Periodical articles}

(31) Ahearn, Kerry. "Family and Adultery: Images and Ideas in Updike's Rabbit Novels." Twentieth Century Literature 34 (1988). 62-83.

Interprets images in the Rabbit novels related to adultery in the family and money matters. Good article depicting the process of degradation due to infidelity.

(32) Armstrong, Peggy. “Updike's Rabbit, Run.” Explicator 47 (Fall 1988): 46-47.

Explains Rabbit's emotional state throughout the novel by using symbolism in relation to other characters and his poor behavior to cope with social problems.

(33) Atlas, James. "John Updike Breaks out of the Suburbia." New York Times (10 Dec 1978): 60-64.

Valuable biographical article, drawing upon an interview with Updike's friends and family. Little information about the Rabbit novels.

(34) Berryman, Charles. "The Education of Harry Angstrom: Rabbit and the Moon." Literary Review 27 (Fall 1998): 117-26.

Analyzes the use of metaphors in the Rabbit novels; praises Updike's art for the thoughts and feelings of his empathetic hero.

(35) Bodmer, George R. "Rabbit to Roger: Updike's Rocking Version." Journal of Popular Culture 22 (Winter 1980): 111-17. 
Discusses the link of popular culture (music and television) in Updike's novels their role to inform and entertain the masses.

(36) Burgess, Anthony. "Language, Myth, and Mr. Updike." Commonweal 83 (11 Feb 1967): 557-59.

Examines language and myth in Rabbit, Run, although the latter could be further developed in relation to archetypal symbols.

(37*) Campbell, Jeff H. "Light on your Fur: Regeneration in Updike's Rabbit Is Rich." Lamar Journal of the Humanities 10 (Spring 1984): 7-13.

(38) Chun, Yen. "A Wanderer between the Pagan Ruins and the Church: Modern Man's Dilemma in Rabbit, Run." American Studies 18 (Mar 1988): 1-28.

Points out Harry's dilemma in Rabbit, Run with regard to the problems of modern man and his insecurities. Good philosophical article in terms of Harry's ideology.

(39) De Bellis, Jack. "Oedipal Angstrom." Wascana Review 24 (Spring 1990): 45-59.

Analyzes the protagonist's actions according to his Oedipal behavior toward his wife and lover. Very good article in terms of archetypal symbols.

(40*) _ . "The Extra Dimension: Characters' Names in Updike's Rabbit Trilogy." Journal of the American Name Society 36 (Mar 1998): 29-42. 
(41) Edwards, Thomas R. “Updike's Rabbit Trilogy.” Rev. of Rabbit Is Rich, by Updike. Atlantic 248 (Oct 1981): 94-102.

Gives a good chronological analysis of the Rabbit Trilogy favoring Rabbit Is Rich for being a fine story of economic life in America. However, criticizes Updike for spending the whole novel of Rabbit, Run not finishing a book on American history.

(42) Ellison, James. "Rabbit is Buying Krugerrands." Rev. of Rabbit Is Rich by Updike. Psychology Today 15 (Oct 1981): 110-16.

Criticizes the novel because social commentary is not integral to the plot; thinks that sadness is the heart of the novel and not wealth.

(43) Fairlie, Henry. "A Decade of Reaction." New Republic 180 (Jan 1979): $15-19$.

Explains people's reactions during the ' 60 s and '70s. Good essay to understand the American history behind the Rabbit novels.

(44) Falke, Wayne. "Rabbit Redux: Time / Order / God." Modern Fiction Studies 20 (Spring 1974): 59-75.

Praises the way Updike portrays America in the ' 60 s and explains the relation between sex and religion in the novel. Thinks that Updike owns a rare verbal genius, a gifted intelligence and a sense of tragedy made bearable by wit.

(45) Gill, Brendan. "A Special Case." New Yorker 47 (Jan 1972): 83-85. 
Praises Updike's creation of Rabbit, Run and Rabbit Redux for its sequence and maturity; fairly short, but insightful.

(46) Horvath, Brooke. "The Failure of Erotic Questing in John Updike's Rabbit Novels." Denver Quarterly 23 (Fall 1988): 70-89.

Analyzes characters and sex in the Rabbit novels by using strong imagery. Thinks that sex scenes are tasteless and deplorable for the American people, this being Updike's black spot. Opposite of Falke (44).

(47) Hunt, George. "Updike's Rabbit Returns." Rev. of Rabbit Is Rich by Updike. America 145 (Nov 1981): 321-22.

Similar to Edwards (41) praising Updike's Rabbit Is Rich as the finest, liveliest and most resourceful of the three novels. Shows highlights of his writing like words coming to life from the paper when his creations are dialoguing. . "John Updike's Sunday Sort of Book." America 132 (June 1975): 477-80.

Stresses Updike's religious themes and rituals in Rabbit, Run and Rabbit Redux. Interesting view about religious matters and culture in which the assumptions and obsessions that control our daily lives are explored in tantalizing detail.

(49) Jackson, Edward M. "Rabbit Is Racist." College Language Association Journal 28 (June 1985): 444-51.

Argues against Rabbit's behavior in the novel Rabbit Redux toward black Americans and Hippies. Insightful reflection of 
people's behaviour during the 60s; time in which Rabbit turns out to be a very unlikable character.

(50) Klinkowitz, Jerome. "John Updike's America." North American Review (Sept 1980): 68-71.

Shows how living and writing in America have formed the substance of Updike's published works and his well-earned reputation. He turns out the flaws in his characters and relationships, simultaneously affirming their worth.

(51) Neary, John M. “Ah, Runs: Updike, Rabbit, and Repetition." Religion and Literature 21 (Spring 1990): 89-110.

Covers the same area as Waldmeir (68), but gives more emphasis to religious implications in relation to marriage and infidelity. Believes there is a vaguely sickening feeling in this book, as one can see the disasters coming.

(52) Lasseter, Victor K. "Rabbit Is Rich as a Naturalistic Novel." American Literature 61 (1989): 429-45.

States several reasons in order to demonstrate why this novel is a naturalistic one, beginning with the title which is ironic. Shows the family as a reflection of its times and social transformation.

$\left(5.3^{*}\right)$ Lemeunier, Barbara S. "The same Thing as Being Dead: Images of Work and Leisure in John Updike's Three Rabbit Novels." Actes du Collogue 5 (Mar 1990): 3-8.

(54) Martin, John S. "Rabbit's Faith: Grace and Transformation of the Heart." Pacific Coast Philology 17 (Nov 1982): 103-111. 
Discusses Rabbit's transformation and changes from Rabbit, Run to Rabbit Redux, and the importance of these changes for the American people in order to follow their dreams.

(55) Mazurek, Raymond A. "Bringing the Corners Forward: Ideology and Representation in Updike's Rabbit Trilogy." Popular 63 (1989): 241-49.

Interpretation of ideology found in Updike's Rabbit trilogy. Focuses on characters and their inner conflicts in relation to social aspects such as race, religion and politics.

(56) O'Connell, Shaun. "Rabbits Remembered." Massachusetts Review 15 (Summer 1974): 511-20.

Shows how Rabbit, Run and Rabbit Redux can be related to our daily lives. Interesting interpretation of the American people, and their social and psychological problems in the figure of Rabbit.

(57) Petter, Henry. "John Updike's Metaphoric Novels." English Studies 50 (April 1969): 197-206.

Focuses on the use of metaphors in Updike's Rabbit, Run. However, the examples given are not fully explained to understand the main conflicts of our protagonist.

(58*) Petillon, Pierre-Yves. "Hors du Terrier Natal." Critique 40 (Mar 1984): 214-23.

(59) Porter, Gilbert. "From Babbit to Rabbit: The American Materialist in Search of a Soul." American Literature 52 (1988): 265. 
Analyzes the hostile American environment in which Rabbit is trapped in Rabbit Redux. Very similar to O'Connell (56), in the sense that Harry's behavior reflects the frustration of the American people.

(60) Pritchard, William. "In Clover: Rabbit Is Rich by John Updike." New Republic 185 (Sept 1981): 30-32.

Praises Updike's creation of Rabbit Is Rich because of its art and elegant poetry. According to Pritchard this is the best of the trilogy in terms of narrative structure.

(61) Regan, R. A. "Updike's Symbol of the Center." Modern Fiction Studies 20 (Spring 1974): 77-96.

Suggests a new approach to study Updike's art in regard to restrictions of freedom in the mind of his characters.

(62) Ricks, Christopher. "Flopsy Bunny." New York Review of Books 17 (16 Dec 1971): 7-9.

Thoughtful negative review of Rabbit Redux claiming Updike's overprotection toward his characters and the limited freedom they have to reach their goals. Very much like Regan (61).

(63) Samuels, Charles Thomas. "Updike on the Present." New Republic 165 (20 Nov 1971): 29-30.

Incisive review essay on the relations between the Rabbit novels and the limits of Updike's psychological realism. Good essay in terms of psychology. 
(64) Schopen, Bernard A. "Faith, Morality, and the Novels of John Updike." Twentieth Century Literature 24 (1978): 523-35.

Debates Updike's dual morality in relation to the fiction of his novels. Focuses on characters' moral decisions in Rabbit, Run and Rabbit Redux.

(65) Stubbs, John C. "The Search for Perfection in Rabbit, Run." Critique: Studies in Modern Fiction 10 (Spring/Summer 1968): 94-101.

Presents our hero in his limitless quest for perfection. Positive view of Harry in search of his happiness and identity as an American symbol.

(66*) Sy, Marieme. "John Updike: Face a l'absurde." Univ. de Dakar Annales de Fac. 10 (1980): 221-41.

(67) Updike, John. "Why Rabbit Had to Go." New York Times Book Review 5 (Aug 1990): 24-25.

Explains why Rabbit leaves his house and still keeps running in Rabbit, Run to search for his identity. Updike examines the experiences of his young hero who is trapped in an unfulfilling life.

(68) Waldmeir, Joseph. "It's the Going that's Important, Not the Getting There." Modern Fiction Studies 20 (Spring 1974): 13-27.

Analysis of Harry Angstrom's running in search for his identity in Rabbit, Run, similar to stubbs (65), but with a more precise symbolism in his quest for happiness. 
(69) Waldron, Randall H. "Rabbit Revised." American Literature 56 (Mar 1984): 51-67.

Points out the significance of the differences among the three revised texts of Rabbit, Run. Very thoughtful essay in order to understand the reasons for the final changes in this novel.

(70) Wilhem, Albert E. “Updike's Revisions of Rabbit, Run." Notes on Modern American Literature 5 (Summer 1981): 15.

Interesting essay pointing out the scope of Updike's revisions in Rabbit, Run. Gives many reasons behind these changes and how they shocked many readers with explicit descriptions of sexuality.

(71) . "Rabbit Restored: A Further Note on Updike's Revisions." Notes on Modern American Literature 6 (Spring 1982): 7.

Gives more reasons behind Updike's motives for revising Rabbit, Run. Similar to his first essay in the Summer 1981 issue of NMAL. 